\title{
Between Sea and Land: Geographical and Literary Marginality in the Conversion of Medieval Frisia
}

\author{
Carole M. Cusack (ii)
}

Citation: Cusack, Carole M. 2021. Between Sea and Land: Geographical and Literary Marginality in the Conversion of Medieval Frisia. Religions 12: 580. https://doi.org/ $10.3390 /$ rel12080580

Academic Editor: Samuel Youngs

Received: 15 April 2021

Accepted: 25 July 2021

Published: 28 July 2021

Publisher's Note: MDPI stays neutral with regard to jurisdictional claims in published maps and institutional affiliations.

Copyright: (C) 2021 by the author. Licensee MDPI, Basel, Switzerland. This article is an open access article distributed under the terms and conditions of the Creative Commons Attribution (CC BY) license (https:// creativecommons.org/licenses/by/ $4.0 /)$.
Department of Studies in Religion, University of Sydney, Sydney, NSW 2006, Australia; carole.cusack@sydney.edu.au

\begin{abstract}
Ancient and medieval Frisia was an ethno-linguistic entity far larger than the modern province of Friesland, Netherlands. Water outweighed land over its geographical extent, and its marginal political status, unconquered by the Romans and without the feudal social structure typical of the Middle Ages, made Frisia independent and strange to its would-be conquerors. This article opens with Frisia's encounters with Rome, and its portrayal in Latin texts as a wretched land of water-logged beggars, ultimately unworthy of annexation. Next, the early medieval conflict between the Frisians and the Danes/Geats, featured in Beowulf and other epic fragments, is examined. Pagan Frisia became of interest during Frankish territorial expansion via a combination of missionary activity and warfare from the seventh century onward. The vitae of saints Willibrord, Boniface, Liudger and Wulfram provide insights into the conversion of Frisia, and the resistance to Christianity and Frankish overlordship of Radbod, its last Pagan king. It is contended that the watery terrain and distinctive culture of Frisia (pastoralism, seafaring, Pagan religion) as noted in ancient and medieval texts rendered it "other" to politically centralized entities such as Rome and Francia. Frisia was eventually tamed and integrated through conversion to Christianity and absorption into Francia after the death of Radbod.
\end{abstract}

Keywords: Frisia; Rome; Francia; geography; paganism; Christianity; missions

\section{Introduction: Rome and Frisia}

The modern province of Friesland in the Netherlands is 5741 square kilometres of thinly populated, low-lying land, the occupants of which possess a language and customs separate from those of the Dutch. Five uninhabited and two inhabited West Frisian Islands are included in the province. Much terrain is below sea level, and the highest point is approximately $15 \mathrm{~m}$ above sea level. Friesland in the north consists of canals, lakes and other waterways; the south consists of fens and heath, marshes with clayey soil, and polders (Niederhöfer 2010). There is only one major town, the capital Leeuwarden, and one notable port, Harlingen. Modern Friesland is smaller than medieval Frisia, which included the province of Groningen in the Netherlands and the provinces of Ostfriesland and Nordfriesland in Germany. This article reviews Frisia's interactions with ancient Rome and medieval Francia to demonstrate the otherness of the Frisians' geographical environment, religion and culture. The sources employed include Tacitus, Pliny the Elder, Beowulf, Gregory of Tours, and the vitae of saints Willibrord, Wulfram, Boniface and Liudger. It is argued that Rome's failure to incorporate Frisia and Francia's long and hard-fought conversion of the Frisians were substantially due to the watery terrain and decentralized society of the Frisians.

The Roman general Nero Claudius Drusus conquered Frisia in 12 BCE and Roman texts shed some light on Frisian culture and politics from that date onward. Drusus taxed the hides of cattle farmed by Frisians leniently, and in 29 CE Frisia revolted against Olennius, an official who raised the tax. The Frisians expelled the Romans, humiliating Emperor Tiberias, and retained their independence until the general Corbulo sailed up the Rhine in 47 CE (Springer 1953, pp. 109-11). Pliny the Elder took part in Corbulo's 
victorious campaign against the neighbouring Chauci, which the Frisians greeted with conciliation. In Book XVI of his Natural History, Pliny appears puzzled that people living what he regards as a miserable existence in the far north were unwilling to accept conquest by Rome:

a wretched race is found, inhabiting either the more elevated spots of land, or else eminences artificially constructed, and of a height to which they know ... that the highest tides will never reach. Here they pitch their cabins; and when the waves cover the surrounding country ... so many mariners on board ship are they: when ... the tide recedes, their condition is that of ... shipwrecked men ... [Y] et these nations, if this very day they were vanquished by the Roman people, would exclaim against being reduced to slavery! (Pliny the Elder 1855, Book XVI, sct. 1)

Emperor Claudius ordered Corbulo to retreat to the west bank of the Rhine (Vandermeulan 1998, p. 2), ending direct Roman interference in Frisian affairs. Tacitus states that the Frisians were resentful of Rome's claims to lands in their vicinity; the occupation of the Rhine riverbank opposite Cologne in 58 CE by Frisians under Verritus and Malorix, of whom Tacitus says they "exercised over the tribe such kingship as exists in Germany" (Tacitus 1937, pp. 94-95; Potter 1992) demonstrates this. Nero gave the leaders Roman citizenship and ordered them to vacate the land. They refused and the Romans expelled them; another tribe, the Ampsivarii, then occupied the site, which suggests resentment of Roman overlordship was potentially widespread.

Much of Frisia was approximately $150 \mathrm{~km}$ north of the limes dividing Germania Inferior from the 'barbarians' outside, but Roman artefacts are found throughout Frisian territory, clustered in the artificial mounds (called wierden in the north and terpen in the south, from the terms for 'village' or 'hamlet') which were constructed from c. 600 BCE to enable successful settlement of the low-lying land (TeBrake 1978, p. 5). These finds are mostly Samian Ware and coins, and are possibly linked to the trade with Romans in Friesian cattle (Galestin 1999-2000, pp. 225-35). Winsum, a site on the saltmarsh that was settled in the sixth century BCE and may have become a Roman military support station, yielded Roman objects from the Augustan period onwards (Galestin 1999-2000, p. 223). The archaeological data are complicated by objects being located in later strata, the ground having been disturbed through "constructing foundations for new houses, raising sections of the terp, or building dams and dykes"' (Galestin 2010, p. 71). Michael Erdrich claimed Roman finds were imported briefly and at specific times, as there was no regular trade between Rome and Frisia (cited in Derk de Weerd 2004-2005, pp. 339-64). In contrast, Marjan C. Galestin argued that archaeological and textual sources support regular contact between Frisians and Romans through Frisians serving in the Roman army and commerce involving both groups. Military campaigns are described in first-century Latin texts; later inscriptions on gravestones and altars indicate trade as the main relationship. An altar dedicated to a local goddess, Hludana, from Beetgum terp referred to Romans who had leased fisheries in the region (Galestin 2010, p. 75). Frisian veterans brought Roman artefacts home, and trade with Rome decreased as the empire faded in the fourth and fifth centuries.

Frisia's geography impacted Rome's lack of interest in permanent conquest. Cassius Dio noted that Drusus' ships ran aground in the 'lake' when he invaded the Chauci after pacifying the Frisians (Cassius Dio 1917, pp. 365-67); this refers to the treacherous Waddenzee (Wadden Sea), a vast, shallow body of water, mud flats and intertidal sands covering more than a million hectares (Krauss 2005). Due to geography, Frisia was a decentralized society lacking unified government, and settlements were small and separated by waters; the construction of dykes began in the eleventh century but land reclamation was not successfully achieved until the fourteenth century or later. Adriaan Verhulst argues that late antique Frisia lacked distinctions between farmers and traders, and "settlements were morphologically very close to the later, small, one street towns" of the early medieval era (Verhulst 1994, p. 370). Trade by sea with Rome is confirmed at Feddersen Wierde 
near Bremerhaven, Germany, approximately $350 \mathrm{~km}$ from the limes (rendering an overland route unlikely). This site was "settled during the last half of the 1st century B.C. and was abandoned during the 5th century A.D." (Parker 1965, p. 1). Roman finds include pottery, glassware, and fibulae. Additionally, the route "by land from Italy to the Frisian coast" (following the Rhine) was in use from Roman to pre-Carolingian times, as attested by "finds of Ostrogothic silver coins and those of the Exarchate of Ravenna in the middle Rhine region" (Adelson 1960, pp. 277-78). The ephemeral qualities of Frisia's watery landscape, and the rebellious independence of the Frisians who rejected incorporation into the Roman Empire, facilitated Frisian separateness and maintained a distinctive Frisian culture until the seventh century, when Frankish coins are found in archaeological sites. From then on, Frisia is usually viewed-questionably, as will be seen-in terms of Frankish overlordship (Croix and Ijssennagger-Van Der Pluijm 2019).

\section{Early Medieval Frisia in Literature and Archaeology}

Early medieval Frisia covered a large expanse of territory, "roughly from Bruges in Belgium to the estuary of the Weser in northern Germany" (Stein-Wilkeshuis 1997, p. 18). The Frisians of this era are visible in literary and historical texts and the archaeological record. The Anglo-Saxon poem Beowulf (c. $800 \mathrm{CE}$ ) devotes approximately one hundred lines to the "Finnsburg Episode", in which King Hrothgar the Dane's scop (bard) sings of a feud between the Frisians and the Danes. This tale is told on the second of three nights the Geatish hero Beowulf spends in Heorot, Hrothgar's hall, during which he kills the monstrous Grendel and his mother (Bremmer 2004, p. 4). The Dane Hnaef is killed by Finn, son of the Frisian king Folcwalda and husband of his sister Hildeburh, while a guest in Finn's hall. In the resulting melee, there are many casualties on both sides, including Finn's son (Bremmer 2004, p. 5). Finn later met his end at the hands of Hengest, one of Hnaef's band (Hewett 1879, pp. 6-7), and Hildeburh was taken back to Denmark. This conflict is the topic of the 48 line Finnsburh Fragment, and Finn is mentioned in another poem, Widsith, an idealised treatment of a scop and the rulers he has known (Hostetter 2021). Rolf H. Bremmer notes that in Beowulf, Finn's hall is portrayed as filled with treasures, and after Finn's death, the Danes took "all the household-property of the king of that country, such jewels, skilfully wrought gems as they were able to find in Finn's home" (Bremmer 2004, p. 6).

Beowulf also contains four references to a raid on Frisia by King Hygelac, in which Hygelac was killed and his champion Beowulf, after slaying the Frisian champion Dæghrefn, had to swim home to Geatland (Bremmer 2004, p. 7). ${ }^{1}$ The motive for this raid also seems to be treasure and glory, and Bremmer notes that in the sixth century, Frisia expanded its reach and became prosperous through trade, with Dorestad emerging as a crucial entrepôt (van Es and Verwers 2010). The Frisians controlled "all the major river estuaries of North-Western Europe; the Scheldt, the Meuse, the Rhine, the Ems and the Weser", which meant that "all kinds of luxury goods-including glass, wine, pepper, pottery, querns, jewellery and woolen fabric - passed from the Rhineland through Frisian staples and were shipped by Frisians to England and Scandinavia" (Bremmer 2004, p. 13). Stéphane Lebecq observes that Frisian traders returned home with grains, timber, slaves, precious stones, and other valuable materials such as amber, and wool to make cloth (Lebecq 1983). Hygelac's raid is an important part of Beowulf, in that it has been used to narrow the dating of its composition. Craig R. Davis proposes that the emergence of the Danes as a polity and the powerful Scylding dynasty is a concern for the Beowulf poet, and an interest in Danish identity is thus discernible in his audience (Davis 2006, p. 116). This points to a late ninth-century origin at the court of Alfred the Great (849-899) as Alfred "traced his father's ancestry to Scyld [and] his mother's ancestry through the Jutish kings of Wight to Goths and Geats" (Davis 2006, p. 111).

The Danes are mentioned in historical sources from the sixth century onwards, including Procopius, Jordanes, Gregory of Tours, and Bede. Gregory names Chlochilaichus 
(cognate with Hygelac) as a Danish (not Geatish, as in Beowulf) king who invaded Frankish lands (Frisian, as in Beowulf) in c. 520 CE in Book 3, Chapter 3 of Historia Francorum:

The Danes sent a fleet under their king Chlochilaich and invaded Gaul from the sea. They came ashore, laid waste one of the regions ruled by Theuderic and captured some of the inhabitants. They loaded their ships with what they had stolen and the men they had seized, and then they set sail for home. Their king remained on the shore, waiting until the boats should have gained the open sea, when he had planned to go on board. When Theuderic heard that his land had been invaded by foreigners, he sent his son Theudebert to those parts with a powerful army and all the necessary equipment. The Danish king was killed and the enemy fleet was beaten in a naval battle and all the booty was brought back on shore once more. (Gregory of Tours 1974, p. 163)

Hygelac, in Gregory's Historia, died in northern Gaul; two centuries later, the Liber Historiae Francorum states that he invaded the lands of the Attoarii/Chattuarii (the Hetware in Beowulf) and died near Nijmegen (Currie 2020, p. 393). Bremmer concludes the prominence of Hygelac's raid in Beowulf and other texts meant that "Frisia played a remarkable role in the political realities of both the Danish and the Geatish courts" (Bremmer 2004, p. 11). The Liber Monstrorum (Book of Monsters), an Anglo-Saxon text from the late seventh or early eighth century, identifies Hygelac as a Geat (such as in Beowulf) and a giant, and claims that " $[\mathrm{h}]$ is bones are preserved on an island in the river Rhine, where it breaks into the Ocean, and they are shown as a wonder to travellers from afar" (Burbery 2015, p. 319). The discovery of Doggerland, the submerged land bridge between England and the Netherlands, which is rich in Pleistocene mammoth fossils, offers a possible explanation for this spectacular phenomenon (Burbery, pp. 317-55). This remarkable modern find neatly links the remote, watery geography of the Frisians with the monstrous and the marvelous.

\section{Missions to the Frisians: Wilfrid and Willibrord}

Missions were core activities for Christians: peoples that did not convert to Christianity were damned. Christian rulers and missionaries thought Pagan customs and laws were at best invalid, and at worst, demonic (Cusack 2013, pp. 65-80). In 797, Alcuin of York wrote to Bishop Speratus, "Quid Hinieldus cum Christo?" (What has Ingeld-another hero from Beowulf - to do with Christ?) (Bullough 1993, pp. 93-125). Anglo-Saxon aristocrats enjoyed heroic poems about Pagan ancestors, but clerics tended to dismiss them as irredeemable. Bremmer argues that literacy reached Frisia in approximately $1200 \mathrm{CE}$, though he notes that Frisians were familiar with books as objects due to missions, and that the Lex Frisionum, the oldest Frisian law code, was drafted in Latin before 802 (Bremmer 2014, pp. 3-4). There are no early medieval texts by Frisians (Mostert 2010, p. 450); ${ }^{2}$ what Frisians thought of missions and political absorption into Francia and Christianisation must be extracted from hagiographies and annals produced by pro-Frankish clerics (Bartlett 1998, p. 56). ${ }^{3}$

Thus, the history of medieval Frisia is written by the state that sought to obliterate it, whose rulers promoted Christianity and campaigned to eliminate the traditional religion of the Frisians (Van der Pol 2015, p. 21). The conquest of Frisia began in Pepin II's reign (680-714), continued through that of his son Charles Martel (714-741) and his great-grandson, Charlemagne (768-814). The region south of the Weser and Rhine Rivers was absorbed in 695 by Pepin; then Charles Martel extended Frankish territory "from Friesland to Vlieland, and the areas around Utrecht and the Veluwe to the Ijssel River, in the middle of the present-day Netherlands" (Van der Pol 2015, p. 21). When Pepin died in $714 \mathrm{CE}$, a large-scale rebellion against the Pippinids broke out, uniting its enemies. Pepin's heir Grimoald, who married Theudesinda, daughter of the Frisian King Radbod (Redbad), also died in 714 (Bremmer 2020, p. 4). Radbod sailed up the Rhine as far as Cologne and re-took Dorestad in 717. Charles Martel subsequently restored order, and when Radbod died, he had no successor to resist Frankish colonisation and Christianity. Yet, parts of Frisia east of the Zuider Zee and extending to the River Weser stayed Pagan and were made Christian by the Franks only in Charlemagne's brutal campaigns against the Saxons 
(772-809 CE), which ended the independence of the last two Pagan peoples in Carolingian lands (Cusack 2011, pp. 44-45).

Richard E. Sullivan's study of Carolingian missions from c. 687 to 900 CE notes two incompatible ideas that underpinned Christian missions: first, that Christianity was a superior religion and persuasion alone would prevail in "making pagans receptive to Christianity as a substitute for their existing religion" (Sullivan 1994, chp. I, p. 273); and second, that the evils of Paganism justified coercion, including political pressure and military action. The first mission to the Frisians was that of Wilfrid of Hexham, who according to Bede and Wilfrid's hagiographer Eddi visited Frisia en route to Rome in 678 CE. Eddi says Wilfrid was well received by King Aldgisl and "he baptised all but a few of the chiefs and many thousands of the common people" (Eddi 1983, p. 132). ${ }^{4}$ Wihtberht, an English monk living in Ireland, was sent by Egbert of Ripon to Frisia in 680 and evangelised for two years, but the new ruler, Radbod was hostile to Christianity; his hostility was probably enabled by the assassination of Dagobert II on 23 December 679. No trace of Wilfrid's mission remained (Levison 1946, p. 53). In 690, Egbert sent Willibrord (c. 658-739) on mission to the Frisians (Colgrave and Mynors 1969, p. 481). Pepin II became Willibrord's patron; he was consecrated archbishop of Utrecht in 695 by Pope Sergius I, who named him 'Clement'. His writings are lost, and the later Vita Willibrordi by Alcuin is of limited historical merit. Pippinid patronage brought Willibrord success, but outside the limits of Frankish military protection he made less progress.

Utrecht became a centre for the production of texts for the Frisian mission. Marco Mostert, discussing written culture in Frisia, records King Aldgisl's response to a letter he received from the Frankish duke Ebroin during Wilfrid's tenure in Frisia, offering a reward for Wilfrid's head: "the king ripped apart the parchment and threw the pieces into the fire ... Aldgisl communicated in a telling visual image to the Frankish messengers that he did not accept the proposition" (Mostert 2010, pp. 461-62). This anecdote is of interest as it confirms Frisian hostility to the Franks prior to the reign of Radbod and indicates that Christianity (in the form of Wilfrid, an Anglo-Saxon), divorced from Frankish territorial ambitions, was perhaps not unacceptable. After Willibrord received the pallium in 695, he used Utrecht as a base for the mission to the Danes and Frisians. Willibrord met Radbod after a failed venture to Denmark, when he landed on an island dedicated to Fosite (Maclear 1869). Cattle were reserved for the deity, and water from the sacred spring must be collected in silence. Willibrord was unintimidated; he baptised three people (probably ransomed Danish boys) in the spring and instructed his company to kill and eat the cattle as required. The Frisians were shocked: "they expected that the strangers would become mad or be struck with sudden death. Noticing, however, that they suffered no harm, the pagans, terror-stricken and astounded, reported to the king what they had witnessed" (Alcuin 1954, p. 10). ${ }^{5}$

Radbod cast lots thrice daily for three days hoping to mandate Willibrord's execution, but was unsuccessful:

The lots of death never fell upon Willibrord nor ... his company, except in the case of one of the party, who thus won the martyr's crown. The holy man was then summoned before the king and ... upbraided for having violated the king's sanctuary and offered insult to his god. [Willibrord] replied 'The object of your worship, O King, is not a god but a devil, and he holds you ensnared in rank falsehood in order that he may deliver your soul to eternal fire ... Be baptized in the fountain of life and wash away all your sins ... ' [Radbod] was astonished and replied: 'It is clear to me that my threats leave you unmoved and that your words are as uncompromising as your deeds'. However, although he would not believe the preaching of the truth, he sent back Willibrord with all honour to Pippin, King of the Franks. (Alcuin 1954, pp. 10-11)

Willibrord and Wulfram were unsuccessful in their attempts to convert Radbod: both explained Christian theological ideas about the afterlife of damned Pagans, to him but the king was unmoved. He did, however, permit both to depart alive. 


\section{Radbod and Frisia: Politics and Religion}

Radbod appears in the hagiographies of several missionaries (Willibrord, Boniface, Wulfram, and Liudger) and in numerous historical texts, including the Liber Historiae Francorum, the Continuations of the Chronicle of Fredegar, the Annales Mettenses Priores, and some minor chronicles. He played an important role in the rise of the Pippinids, and the eclipse of Neustria by Austrasia (Meens 2015, p. 578). He is referred to both as 'duke' and 'king', and while he gave his daughter in marriage to Grimoald son of Pepin II, after both died in 714, he joined forces with their enemy, the Neustrian mayor of the palace Ragamfred, and opposed Pepin's illegitimate son Charles Martel (Broome 2015, p. 161). Radbod is portrayed as a great seafaring commander who inflicted the only recorded defeat on Charles Martel when he re-took Dorestad in 717. After this victory, he experienced an illness and died in 719 (Broome 2015, p. 179). Charles Martel then brought "all of Friesland west of Lake Flevo definitively ... under Frankish dominion" (Mostert 2013, p. 121). Certain sources accord greater significance to Radbod; for example, the Continuations omits Pepin II's campaigns against the Suevi to focus on the Frisians and their formidable ruler, who acted as a religious and a military leader (Wood 1995, p. 258).

Sources for the Frisian missions portray Radbod primarily as a Pagan and an opponent of conversion to Christianity (Broome 2014). This is always contextualized in terms of Frankish political ambitions and patronage of missions; Bede describes the missions of Wilfrid, Wihtberht and Willibrord, and notes that as "Pippin had recently occupied Frisia citerior and driven out King Radbod, he sent Willibrord and his companions there to preach; and he assisted them with his imperial authority so that no troubles would interfere with their preaching" (Colgrave and Mynors 1969, Book X). The implication is clear; Frankish overlordship signifies Christianity, and areas that the Franks do not control are outside of the Christian faith (Bremmer 1992). ${ }^{6}$ Willibald's Vita Bonifatii, written approximately a decade after Boniface's martyrdom at the hands of Frisian Pagans at Dokkum in 754 CE, records Boniface's arrival in Frisia in 716, in the midst of the conflict between Radbod and Charles Martel. Radbod expelled Christians from Frisia, and restored idols and temples, that is, reinstated the Pagan religion. Alcuin, writing in c. 796 CE, regards Radbod as an obstacle to the conversion of the Frisians, such that his death was a boon, but as a ruler that Willibrord had civil dealings with (Broome 2015, p. 159). The Vita Vulframni, portraying Radbod at a time prior to his meeting with Willibrord in 696 (the likely year of Wulfram's death), shows the Frisian king permitting Christian preaching and allowing Wulfram to make converts among those he redeems from sacrificial death (Glaister 1878). Jonas of Fontenelle actually states, "nor did the aforementioned chieftain [Radbod] forbid that the word be preached ... even the son of the same Radbod [was baptised] ... clean, as is believed, he passed over out of the world" (Jonas of Fontenelle 2021, chp. IV), see Supplementary Materials. ${ }^{7}$

The Vita Vulframni was written at Fontenelle in the late eighth or early ninth century; the author identifies himself as Jonas, a monk of that foundation (Effros 1997, p. 272). The text has had a checkered history as a source for missions to the Frisians. Wilhelm Levison, editor of the Monumenta Germaniae Historica, termed Wulfram's travels to Frisia "a famous legend" (Levison 1946, p. 56), yet favoured a relatively early date of between 788 and 811 for the text. Stéphane Lebecq regards Wulfram as "le principal animateur" of evangelism to the Frisians, more significant than Willibrord, and follows Levison in dating the saint's life to 788-811, when Fontenelle enjoyed a renaissance under Abbot Gervold (Lebecq 2000, p. 75). Lebecq argues the Vita is a compendium of earlier compositions; for example, the dedication to Bainus refers to the abbot of Fontenelle from 701-710, and the core of information regarding pre-Christian Frisian religion comes from Frisian informants such as Ovo, a boy saved by Wulfram from sacrificial death (Lebecq 1996, p. 776). Wulfram was born at Milly near Fontainebleau and, after being ordained priest, won the favour of Theodoric III (c. 651-691) of Neustria and became bishop of Sens (Mershman 1912). Lebecq considers that this elevation occurred in $687 / 8$ and that Wulfram resigned the pallium and became a missionary to the Frisians in approximately 690 , the same year Willibrord was 
sent to Frisia by Egbert (Lebecq 2018, pp. 555-68). Wulfram retired to Fontenelle and died in 696/7 (though it has been proposed he may have lived to 703, which suggests his body was translated one year after his death) (Howe 2001, p. 153).

By contrast, Ian Wood has argued that the text is a fraudulent answer to Alcuin's Vita Willibrordi, asserting a Neustrian claim against Boniface's Austrasian connections, which nevertheless provides reliable anthropological data about Radbod and Frisian customs, or how later authors such as Alcuin understood Radbod and Frisian customs (Wood 2013). Lebecq rejects Wood's contention that the Vita Vulframni was deliberately composed to challenge the Vita Willibrordi, in that Wulfram was a Neustrian and Willibrord was effectively in service to the Austrasian Pippinids (Wood 2001, pp. 92-94). Wood's argument, which unlike Lebecq's has not been developed to any length, but rather exists as a briefly expounded aside in studies that are about other aspects of Germanic Christianisation (Wood 1995, 2001, 2008, 2013), turns on the chronological anomalies in the text, and simply rejects its authenticity without further ado. Admittedly, there are issues with the text; the most obvious is that the date of Wulfram's death is given as 720 and Bainus' translation of his relics is accordingly shifted to 729 (Howe 2001, p. 158). Lebecq argues that the author of the Vita Vulframni was acquainted with Jonas of Bobbio's Vita Columbani, Gregory of Tours' Decem Libri Historiarum, Bede's Historia Ecclesiastica, the Vita Sancti Amandi and the Miracula Amandi (Lebecq 2000, p. 77). ${ }^{8}$ For Lebecq, the composite text we have potentially consists of: an original biography, perhaps composed for Abbot Bainus' translation of Wulfram's body in 704; two miracle stories (healing the sick and rescuing a paten from the sea) which he attributes to Abbot Wando who was supposedly in Frisia with Wulfram (he became abbot in 742 and died c. 756); and the descriptions of the saint's missionary activities in Frisia, which are from Ovo, the Frisian eyewitness who became a monk of Saint-Wandrille (Lebecq 2000, pp. 83-84). Considering these elements, Lebecq concludes that Wulfram's mission has "un caractère d'authenticité indéniable et que leur originalité absolue oblige l'historien à reconnaître l'existence d'une connexion entre le monastère neustrien et la Frise lointaine" (Lebecq 2000, p. 87).

Radbod also features in the lives of two saints who were active long after his death, Boniface and Liudger. Unsurprisingly, Willibald's Vita Bonifatii emphasizes Radbod's Paganism: Boniface opposed Pagans during his mission, although there was a political dimension to his activities and heterodox Christianity was as much of a target as Paganism. For example, Boniface's encounter with the Thuringian rulers Theobald and Heden, who allowed people to regress to "rustic" or "heretical" practices, is reported without reference to Heden's support of Willibrord and his monastery at Echternach (Broome 2015, p. 162). Richard Broome argues that Willibrord's depiction of Radbod, "which present[s] him as a hostile, pagan king" tends to "overlook the pro-Christian connotations of his relations with both Pippin II and the Neustrians Chilperic II and Ragamfred" (Broome 2015, p. 161). Altfrid's Vita Liudgeri, a hagiography of an Utrecht-born saint, contains an account of Radbod's last illness, and it is clear from the changed historical context (Liudger's dates are c. 742-809) that Christian missions went more smoothly after the Pagan Frisian ruler's death.

\section{The Vita Vulframni: The Missionary and the Sea}

The Vita Vulframni has generally been regarded as a reliable source of information about pre-Christian Frisian religion; for example, Wood, who has repeatedly argued that it is a "forgery" nevertheless accords credibility to it descriptions of lot casting and sacrificial death by drowning (Wood 1995, p. 260). In 2015, Rob Meens took a moderate stance regarding its reliability; he argued that even if the content was not true or accurate, it nevertheless informed readers about "the insecurity about the fate of pagan forefathers" and the "way in which Wulfram and Radbod were remembered at the time of composition of the Vita" (Meens 2015, p. 580). The most significant element of the portrayal of human sacrifice in the service of Pagan gods in the Vita Vulframni is the role played by the sea, which is linked to the watery geography of Frisia itself. Chapter V of Vita Vulframni tells how Wulfram of Sens celebrated Mass on board ship while en route to Frisia; during 
the ceremony the paten fell into the sea. Wulfram prayed and "from the deep of the sea the same paten, divinely carried back, stuck fast to the hand of the same attendant" (Jonas of Fontenelle 2021, chp. V). Arguably, this episode contrasts the sacrifice of the Mass with the Pagan space of the waters, and Wulfram's prayers overcoming the loss of the paten in the sea prefigures the triumph of Christianity over Pagan rituals involving the treacherous waters.

Wulfram's Vita mentions victims "led to a certain place surrounded by water in the manner of two seas to be swallowed wretchedly by waves when the current of the sea overwhelmed the same place ... at the time of high tide" (Jonas of Fontenelle 2021, chp. VIII). Wulfram's rescued victims are given names and individual characteristics to make them personalized and meaningful to readers. Chapter VI records that he rescued a lad named Ovo; "[o]n a certain day a certain boy, born of the very nation of the Frisians, was led to the noose to be sacrificed to the gods ... the boy is hanged on the gallows for a period of nearly two hours" (Jonas of Fontenelle 2021, chp. VI); but Wulfram's prayers burst his chains and Ovo was delivered. Ovo later became a monk of Saint-Wandrille and, according to Lebecq, an important eyewitness source for the Vita Vulframni (Lebecq 1994, p. 144). Chapter VIII tells of "a certain widow woman who had two most dear sons, who, by the cast of the lot had been going to be sacrificed to daemons and destroyed in the whirlpool of the sea" (Jonas of Fontenelle 2021, chp. VIII). Wulfram's prayers result in God drying up the land, a direct 'crossing the Red Sea' motif from the Biblical book of Exodus. These boys, too, are baptised after their rescue. These incidences of conversion establish the sea as waters that lead to death, whereas the holy waters of baptism lead to eternal life. There is seemingly a link between lot casting and sacrifice, and a reference in the Lex Frisionum reinforces the practice of sacrifice by rising water which is attested in the Vita Vulframni (Lebecq 2000, p. 86).

The Lex Frisionum is a late Carolingian capitulary dated to 785-793/4 (Popkema 2014, p. 369) that has in the last two decades been studied from the viewpoint of violence and the punishments and reparations it occasions. For example, Han Nijdam has researched the relationship between the measurement of wounds and the fines levied to compensate for them (Nijdam 2000) and Premyslaw Tyszka situates the Lex Frisionum in the context of Germanic law codes and sexual violence against women, free and enslaved (Tyszka 2011). More salient to the argument of this article, Bremmer notes that the most extraordinary linking between the sea and death in the text is the "remarkable punishment to which the desecrator of pagan sanctuaries (fanum) was subjected: he was led to the sea shore, castrated and drowned" (Bremmer 2010, p. 531). This suggests that the sea is a holy place that is associated with the Frisian gods, and that those who profane them have their lives extinguished in the sea, which is a natural element that carried out the divine will. The boys rescued by Wulfram in the Vita Vulframni are presumably not being punished for desecrating sanctuaries (thought there are interesting possibilities in the relation between physical castration and the Christian embrace of celibacy in monasticism), but the Lex Frisionum confirms that death by drowning was an authorised Pagan form of execution.

Chapter IX of the Vita Vulframni gives the account of the "failed baptism" of Radbod (Meens 2015, p. 579), and Chapter X relates how Wulfram destroyed "a house of shining gold and unbelievable beauty" that "his god has vowed that he will bestow on Prince Radbod after his death" (Jonas of Fontenelle 2021, chp. X). The baptism scene is the most important in the hagiography and has attracted interest for many years (Maclear 1863, pp. 175-80; Brown 1910, pp. 141-44). Wulfram and Radbod discoursed as the Frisian king prepared to enter the baptismal font and receive the Christian waters of eternal life:

Furthermore the aforementioned chieftain Rathbod, since he was inspired to receive baptism, inquired of the holy bishop Vulfram, binding him by vows through the name of the Lord, where were the greater number of kings and princes or nobles of the race of the Frisians, namely in that heavenly region, which if he believed and were baptised [Vulfram] promised he would attain, or in that [region] which he was calling infernal punishment. Then blessed Vulfram 
said, 'Do not make a mistake, noble prince, the number of his saved is sure in the hands of God. For it is certain that those of your princely predecessors of the race of the Frisians who passed away without the sacrament of baptism received the sentence of eternal punishment; truly whoever from now on believes and is baptised will rejoice with Christ in eternity'. Hearing this the unbelieving chieftain — for he had gone forward to the font-even, as is related, withdrew his foot from the font, saying that he could not lack the society of his princely Frisian predecessors and dwell with a small number of paupers in that heavenly realm; nay rather that he could not easily show agreement to the new words, but that he would rather be going to remain in these [words] to which for a long time he, with the whole race of the Frisians, had paid heed. But the blessed bishop of Christ said. 'Alas, ah sorrow, I see that you have been tricked by the misleader who deceives humankind! But unless you pursue penitence and believe and are baptised in the name of the holy trinity, you will not enter the gate of the eternal kingdom, but will be punished by the pain of eternal damnation'. When the holy bishop said these things, many of the Frisians believed and were baptised although the aforementioned king persisted in paganism. (Jonas of Fontenelle 2021, chp. IX)

As Meens emphasizes, the main issue is the fate of unbaptised ancestors. Meens notes that although the Vita Vulframni foregrounds this issue, other missionary saints had to deal with it too. For example, Meens argues convincingly that the correspondence between Pope Gregory and Boniface regarding "liturgical offerings for the deceased" indicates some were making liturgical offerings for the non-Christian deceased, that is, they were seeking to honour their Pagan ancestors (Meens 2015, p. 583).

To achieve a fuller interpretation of the failed baptism of Radbod, it would be useful to engage in a detailed comparison with other baptisms of Pagan Germanic leaders, for example, that of the Danish ruler Harald Gormsson, nicknamed Bluetooth, by the German missionary Poppo (Cusack [1998] 2001, p. 145), which succeeded only because Poppo baptised the exhumed corpses of Harald's parents and re-interred them in the church he erected at the royal site of Jelling. However, for the purposes of this article, the loyalty to ancestors expressed in the Vita Vulframni by Radbod is understandable in cultural terms. As James C. Russell puts it, "[s]ocial structure influences ideological structure" and Radbod would therefore prefer an afterlife feasting collectively with his kin than an individual Christian afterlife (Russell 1994, p. 102).

\section{Conclusions}

This article has argued that the sea was the dominant geographical reality for the Frisians in the late Roman and early medieval periods (McManus et al. 2013, pp. 255-77). This was a factor in the potential integration of the Pagan Frisians into the Roman Empire (which did not eventuate) and the Pippinid/Carolingian Christian empire, which happened only after more than three decades of war waged by Charlemagne from 772 onwards (Cusack 2011, pp. 44-46). Evidence of hostility to both Roman and Frankish overlordship has been cited. The watery lands of Frisia were viewed as treacherous by the Romans, and feature as a site of Pagan religion in Jonas of Fontenelle's Vita Vulframni. This article has contrasted the sea (which covers much of Frisia) as a site of sacrifice by drowning to Pagan gods (Wood 2008, p. 726; Bremmer 2010, p. 531), with the waters of baptism that confer Christian salvation. The Christian God's power over the sea is exhibited in the incident of the recovered paten, and the rescue of the boys to be sacrificed by drowning. This is a form of conversion of nature and the landscape in which Christians exercised powers of control and transformation over previously Pagan terrain (Siewers 2003, p. 2).

Due to the importance of marginal landscapes/seascapes in all eras and all characterisations of the Frisians, the idea of transformation of the landscape is important. Early medieval Frisia has largely been understood in terms of Christian Francia in much contemporary and historical research; this is valid given the Christian Franks' sustained efforts to 
conquer and absorb it, and the fact that the transformation of Frisian and Saxon territories included resettling of ethnic Franks in these marginal areas, and the removal of Frisians and Saxons to distant regions of the Frankish empire (Cusack 2011, p. 45). However, it is potentially more useful to see Frisia as a territory that is contiguous with Jutland and linked (like Saxony) with the Scandinavian polity that met aggressive Carolingian evangelism and territorial expansion with sustained sea raiding and hostility (Croix and Ijssennagger-Van Der Pluijm 2019, p. 3). This kinship renders the concerns of Radbod at the font, that integration into the Christian afterlife would deprive him of the society of his ancestors, both more poignant and more urgent, in that the Franks were a colonialist power that sought the obliteration of the Pagan religion and distinctive culture of the peoples they conquered. In Jonas' Vita Vulframni, Wulfram is depicted destroying the marvelous palace the Pagan gods promised Radbod; in effect nullifying the Pagan idea of the afterlife as a banquet in the company of gods and ancestors (Jonas of Fontenelle 2021, chp. X) Yet, the Frisian way of life endured in their watery homeland, unchanged by the Franks and Christianity, until the Vikings, a people equally at home on the sea, took over "their own maritime niche" (TeBrake 1978, p. 28), spelling the end for a distinctive and marginal lifestyle built on reclamation of land from the sea, and commitment to self-determination asserted by the Frisian people.

Supplementary Materials: The following are available online at https: / www.mdpi.com/article / $10.3390 /$ rel12080580/s1. The translation of the Vita Vulframni that accompanies this article is by Andrew Gollan.

Funding: This research received no external funding.

Acknowledgments: I am grateful to Andrew Gollan for translating the Vita Vulframni so expertly and inspiring me to write this article. My thanks are due to Keagan Brewer (Macquarie University) who in the past was both my doctoral student and research assistant. His contribution to the research for this article is considerable. My colleagues at the Australian Early Medieval Association Conference at the University of Sydney, 11-12 February 2016 provided helpful feedback on my presentation which covered some of the same material as this article. All errors are my own.

Conflicts of Interest: The author declares no conflict of interest.

\section{Notes}

1 The relevant sections are Beowulf 1202-14a, 2354a-66, 2501-08a, and 2910b-21.

2 Marco Mostert notes "the Frisian language seems to have been spoken by only some of those we encounter as 'Frisians' in the (early) medieval sources ... next to nothing is known of the language spoken by the 'Frisians' mentioned in Roman sources", p. 450.

3 Robert Bartlett's Raleigh Lecture on History, "Reflections on Paganism and Christianity in Medieval Europe", Proceedings of the British Academy, 101 (1998), 55-76 opines that "To seek to understand native paganism from missionary literature is a little like attempting to form a picture of twentieth-century British socialism from the speeches of Margaret Thatcher. A hostile, sometimes highly ideological and tactically inspired viewpoint is the one we have to deal with", p. 56.

4 The Latin text is Eddius Stephanus, Vita Wilfridi, in Monumenta Germaniae Historica: Scriptorum Rerum Merovingicarum, Bruno Krusch and Wilhelm Levison (eds), Tom. 6 (Hannover: MGH SRM, 1913), pp. 163-263.

5 The Latin text is Alcuin, Vita Willibrordi, in Monumenta Germaniae Historica: Scriptorum Rerum Merovingicarum, Bruno Krusch and Wilhelm Levison (eds), Tom. 7 (Hannover: MGH SRM, 1919), pp. 81-144.

6 Bremmer (1992) notes that Paul the Deacon's Historia Langobardorum contains an obituary for Pepin II that states that "He also courageously waged many wars with the Saxons and especially with Ratpot, King of the Frisians (Book VI, Chapter 37)", p. 6.

7 The translation of Jonas of Fontenelle's Vita Vulframni that accompanies this article is by Andrew Gollan. The Latin text is Jonas of Fontenelle, Vita Vulframni, in Monumenta Germaniae Historica: Scriptorum Rerum Merovingicarum, Bruno Krusch and Wilhelm Levison (eds), Tom. 5 (Hannover: MGH SRM, 1910), pp. 657-73.

8 It is worth noting that Ian Wood, "The Pagans and the Other: Varying Presentations in the Early Middle Ages", Networks and Neighbours, vol. 1, No. 1 (2013), at https://nnthejournal.org (accessed on 31 March 2021) states that the Vita Wulframni [sic] is anonymous (despite the author identifying himself as Jonas of Fontenelle in the opening lines), and repeats the same brief summary he has made in a number of publications, that is, that the text is unreliable, though he admits the desire of Radbod to be with his kin after death is a credible motivation. 


\section{References}

Adelson, Howard L. 1960. Early Medieval Trade Routes. The American Historical Review 65: 271-87. [CrossRef]

Alcuin. 1954. Life of Saint Willibrord. In The Anglo-Saxon Missionaries in Germany. Translated and Edited by C. H. Talbot. New York: Sheed and Ward.

Bartlett, Robert. 1998. Reflections on Paganism and Christianity in Medieval Europe. Proceedings of the British Academy 101: 55-76.

Bremmer, Rolf H., Jr. 1992. Willibrord Through Anglo-Saxon and Frisian Eyes. Friesische Studien 1: 1-28.

Bremmer, Rolf H., Jr. 2004. The Frisians in Beowulf_Beowulf in Frisia: The Vicissitudes of Time. In Medieval English Literary and Cultural Studies. Edited by Juan Camilo Conde Silvestre and María Nila Vázquez González. Murcia: SELIM, pp. 3-31.

Bremmer, Rolf H., Jr. 2010. From Alien to Familiar: Christ in Language and Law of Medieval Frisia. In Myths, Martyrs, and Modernity: Studies in the History of Religions in Honour of Jan N. Bremmer. Edited by Jitse Dijkstra, Jutin Kroesen and Yme Kuiper. Leiden and Boston: Brill, pp. 531-52.

Bremmer, Rolf H., Jr. 2014. The Orality of Old Frisian Law Texts. Amsterdamer Beiträge zur älteren Germanistik 73: 1-49. [CrossRef]

Bremmer, Rolf H., Jr. 2020. 'Thi Wilde Witsing': Vikings and Others in the Old Frisian Laws. The Journal of English and Germanic Philology 119: 1-26. [CrossRef]

Broome, Richard. 2014. Approaches to Community and Otherness in the Late Merovingian and Early Carolingian Periods. Ph.D. thesis, University of Leeds, Leeds, UK.

Broome, Richard. 2015. Pagans, rebels and Merovingians: Otherness in the early Carolingian world. In The Resources of the Past in Early Medieval Europe. Edited by Clemens Gantner, Rosamond McKitterick and Sven Meeder. Cambridge: Cambridge University Press, pp. 155-71.

Brown, Carleton. 1910. The Vernon Disputisoun Bytwene a Cristenemon and a Jew. Modern Language Notes 25: 141-44. [CrossRef]

Bullough, Donald A. 1993. What has Ingeld to do with Lindisfarne? Anglo-Saxon England 22: 92-135. [CrossRef]

Burbery, Timothy J. 2015. Fossil Folklore in the Liber Monstrorum, Beowulf, and Medieval Scholarship. Folklore 12: 317-35. [CrossRef]

Cassius Dio. 1917. Roman History. Translated by Earnest Cary. Cambridge: Harvard University Press, vol. VI, Book 54, Chapter 32, pp. 365-67.

Colgrave, Bertram, and R. A. B. Mynors. 1969. Bede's Ecclesiastical History of the English People. Oxford: The Clarendon Press.

Croix, Sarah, and Nelleka Ijssennagger-Van Der Pluijm. 2019. Cultures Without Borders? Approaching the cultural continuum in the Danish-Frisian coastal areas in the early Viking Age. Scandinavian Journal of History. [CrossRef]

Currie, Edward. 2020. Hygelac's Raid in Historiography and Poetry: The King's Necklace and Beowulf as Epic. Neophilologus 104: 391-400. [CrossRef]

Cusack, Carole M. 2001. The Rise of Christianity in Northern Europe, 300-100. London and New York: Cassell. First published 1998.

Cusack, Carole M. 2011. Pagan Saxon Resistance to Charlemagne's Mission. The Pomegranate: The International Journal of Pagan Studies 13: 33-51.

Cusack, Carole M. 2013. Enlightenment Concepts, Medieval Contexts. In Critical Reflections on Indigenous Religions. Edited by James L. Cox. Farnham and Burlington: Ashgate, pp. 65-80.

Davis, Craig R. 2006. An Ethnic Dating of Beowulf. Anglo-Saxon England 35: 111-29. [CrossRef]

Derk de Weerd, Maarten. 2004-2005. Trade or Controlled Supply? Roman Artefacts in Northwestern Germania. Talanta 36-37: 339-64.

Eddi. 1983. Life of Wilfrid. In The Age of Bede. Edited by D. H. Farmer. Translated by J. F. Webb. Harmondsworth: Penguin.

Effros, Bonnie. 1997. De partibus Saxioniae and the Regulation of Mortuary Custom: A Carolingian Campaign of Christianization or the Suppression of Saxon Identity? Revue Belge de Philologie et d'histoire 75: 267-86. [CrossRef]

Galestin, M. C. 1999-2000. Winsum-Bruggeburen, First Report on the Excavation. An Early Roman Outpost Among the Frisians? Part One: The Roman Coins. Paleohistoria 41-42: 225-35.

Galestin, Marjan C. 2010. Roman Artefacts Beyond the Northern Frontier: Interpreting the Evidence from The Netherlands. European Journal of Archaeology 13: 64-88. [CrossRef]

Glaister, William. 1878. Life and Times of S. Wulfram, Bishop and Missionary. Grantham: Lawrence Ridge.

Gregory of Tours. 1974. A History of the Franks. Translated and Edited by Lewis Thorpe. London: Penguin Classics.

Hewett, Waterman Thomas. 1879. The Frisian Language and Literature: A Historical Study. Ithaca: Finch \& Apgar.

Hostetter, Aaron K. 2021. Widsith. In Old English Poetry Project. New Brunswick: Rutgers University. Available online: https: / / oldenglishpoetry.camden.rutgers.edu/widsith/ (accessed on 22 March 2021).

Howe, John. 2001. The Hagiography of Saint-Wandrille (Fontenelle) (Province of Haute Normandie). In L'hagiographie du haut Moyen Âge en Gaule du Nord. Edited by Martin Heinzelmann. Stuttgart: Jan Thorbecke, pp. 127-92.

Jonas of Fontenelle. 2021. Vita Vulframni. Appended translation by Andrew Gollan.

Krauss, Werner. 2005. The Natural and Cultural Landscape Heritage of Northern Friesland. International Journal of Heritage Studies 11: 39-52. [CrossRef]

Lebecq, Stéphane. 1983. Marchands et Navigateurs du Haute Moyen Âge. Lille: Presses Universitaires de Lille, vol. 2.

Lebecq, Stéphane. 1994. Le Baptême Manqué du roi Radbod. In Les Assises du Pouvoir: Temps Médiévaux, Territoires Africains. Edited by Odilon Redon, Bernard Rosenberger, Robert Delort and Jean Devisse. Saint-Denis: Presses Universitaires de Vincennes, pp. 141-50.

Lebecq, Stéphane. 1996. Vivent les Mérovingiens! French Historical Studies 19: 765-77. [CrossRef]

Lebecq, Stéphane. 2000. Hommes, Mers et terres du Nord au Début du Moyen Âge. Villeneuve d'Ascq: Presses Universitaires du Septentrion. 
Lebecq, Stéphane. 2018. Vulfran, clerc palatin, moine de Fontenelle, evêque métropolitain de Sens. Revue Belge de Philologie et D’histoire 96: 555-68. [CrossRef]

Levison, Wihelm. 1946. England and the Continent in the Eighth Century. Oxford: The Clarendon Press.

Maclear, George Frederick. 1863. A History of Christian Missions During the Middle Ages. Cambridge: Cambridge University Press.

Maclear, George Frederick. 1869. Apostles of Medieval Europe. London: Macmillan \& Co.

McManus, Ellen, Janet Montgomery, Jane Evans, Angela Lamb, Rhea Brettell, and Johan Jelsma. 2013. 'To the Land or to the Sea': Diet and Mobility in Early Medieval Frisia. Journal of Island and Coastal Archaeology 8: 255-77. [CrossRef]

Meens, Rob. 2015. With One Foot in the Font: The Failed Baptism of the Frisian King Radbod and the 8th Century Discussion About the Fate of Unbaptized Forefathers. In Early Medieval Ireland and Europe: Chronology, Contacts, Scholarship. Edited by Pádraic Moran and Immo Warntjes. Turnhout: Brepols, pp. 577-96.

Mershman, Francis. 1912. St Wulfram. In The Catholic Encyclopedia. New York: Robert Appleton Company, vol. 15. Available online: https:/ / www.newadvent.org/cathen/15716a.htm (accessed on 22 March 2021).

Mostert, Marco. 2010. The Early History of Written Culture in the Northern Netherlands. In Along the Oral-Written Continuum: Types of Texts, Relations and Their Implications. Edited by Slavica Ranković, Leidulf Melve and Else Mundal. Turnhout: Brepols, pp. 449-88.

Mostert, Marco. 2013. Communicating the Faith. The Circle of Boniface, Germanic Vernaculars, and Frisian and Saxon Converts. Amsterdamer Beiträge zur älteren Germanistik 70: 87-130. [CrossRef]

Niederhöfer, Kai. 2010. Settlement history of a lost landscape: Archaeological remains in the East Frisian tidal flats. In Science for Wadden Sea Ecosystem and EU Directives, Proceedings of the 12th International Scientific Wadden Sea Symposium in Wilhelmshaven, Germany, 30 March-3 April 2009. Edited by Harald Marencic, Kai Eskildsen, Huber Farke and Stefanie Hedtkamp. Wilhelshaven: Common Wadden Sea Secretariat, pp. 167-72.

Nijdam, Han. 2000. Measuring Wounds in the Lex Frisionum and the Old Frisian Register of Fines. In Philologia Frisica Anno 1999. Lêzingen fan it Fyftiinde Frysk Filologekongres 8, 9 en 10 Desimber 1999. Edited by P. Boersma. Leeuwarden: Fryske Akademy, pp. 180-203.

Parker, Helen. 1965. Feddersen Wierde and Vallhagar: A Contrast in Settlements. Medieval Archaeology 9: 1-10. [CrossRef]

Pliny the Elder. 1855. Natural History. Translated and Edited by John Bostock, and H. T. Riley. London: Taylor and Francis, Book XVI, Section 1. Available online: http:/ / www.perseus.tufts.edu/hopper/text?doc=Perseus\%3Atext\%3A1999.02.0137\%3Abook\%3D1 6\%3Achapter\%3D1 (accessed on 22 March 2021).

Popkema, Anne Tjerk. 2014. Old Frisian: A Legal Language in Principle. Amsterdamer Beiträge zur älteren Germanistik 73: 369-95. [CrossRef]

Potter, David. 1992. Empty Areas and Roman Frontier Policy. The American Historical Review 113: 269-74. [CrossRef]

Russell, James C. 1994. The Germanization of Early Medieval Christianity. New York and Oxford: Oxford University Press.

Siewers, Alfred K. 2003. Landscapes of Conversion: Guthlac's Mound and Grendel's Mere as Expressions of Anglo-Saxon NationBuilding. Viator 34: 1-39. [CrossRef]

Springer, Lawrence A. 1953. Notes: Rome's Contact with the Frisians. The Classical Journal 408: 109-11.

Stein-Wilkeshuis, Martina. 1997. Frisian Law and the Forbidding Northern Countries Overseas. Legal History 18: 17-29. [CrossRef]

Sullivan, Richard E. 1994. Carolingian Missionary Theories. In Christian Missionary Activity in the Early Middle Ages. Richard E. Sullivan (collected). Aldershot and Brookfield: Ashgate Variorum.

Tacitus. 1937. Annals. Translated by John Jackson. London: William Heinemann/Loeb Classical Library.

TeBrake, William H. 1978. Ecology and Economy in Early Medieval Frisia. Viator 9: 1-30. [CrossRef]

Tyszka, Przemyslaw. 2011. Sexual Violence in the Early Medieval West. Acta Poloniae Historica 104: 5-30.

Van der Pol, Frank. 2015. The Middle Ages to 1200. In Handbook of Dutch Church History. Edited by H. J. Selderhuis. Göttingen: Vandenhoeck \& Ruprecht, pp. 17-30.

van Es, W. A., and W. H. Verwers. 2010. Early Medieval Settlements along the Rhine: Precursors and Contemporaries of Dorestad. Journal of Archaeology in the Low Countries 2: 5-39.

Vandermeulan, Jason. 1998. The Frisian Tribe: From Caesar to Charlemagne. The Canadian Journal of Netherlandic Studies XIX: 1-13.

Verhulst, Adriaan. 1994. The Origins and Early Development of Medieval Towns in Northern Europe. The Economic History Review 47: 363-72. [CrossRef]

Wood, Ian. 1995. Pagan Religion and Superstition East of the Rhine from the Fifth to the Ninth Century. In After Empire: Towards an Ethnology of Europe's Barbarians. Edited by Giorgio Ausenda. Woodbridge: The Boydell Press, pp. 253-79.

Wood, Ian. 2001. The Missionary Life: Saints and the Evangelisation of Europe 400-1050. Harlow: Pearson Education Ltd.

Wood, Ian. 2008. Christianisation and the Dissemination of Christian Teaching. In The New Cambridge Medieval History. Edited by Paul Fouracre. Cambridge: Cambridge University Press, pp. 710-36.

Wood, Ian. 2013. The Pagans and the Other: Varying Presentations in the Early Middle Ages. Networks and Neighbours 1. Available online: https:/ / nnthejournal.org (accessed on 31 March 2021). 